\title{
The Fading and Remodeling of Teacher Authority
}

\author{
Jie Chen \\ Hainandao Community, Shanxi University, Taiyuan, China \\ Email: 18634360429@163.com
}

How to cite this paper: Chen, J. (2022). The Fading and Remodeling of Teacher Authority. Open Journal of Social Sciences, 10, 155-162.

https://doi.org/10.4236/jss.2022.101013

Received: December 13, 2021

Accepted: January 14, 2022

Published: January 17, 2022

Copyright (c) 2022 by author(s) and Scientific Research Publishing Inc. This work is licensed under the Creative Commons Attribution International License (CC BY 4.0).

http://creativecommons.org/licenses/by/4.0/

(c) (i) Open Access

\begin{abstract}
As a philosopher, theologian and educator, Karl Theodor Jaspers's research field was extremely wide, and his abundant academic background had a significant influence on his educational theory. Among his numerous works, What is Education mostly embodies his existentialist educational thought. In this book, Jaspers proposed the Authority Theory as the source of education, in line with the educational purpose of cultivating "whole person". As the sole source and essence of education, authority has three characteristics: spirituality, democracy and spontaneity. It can be seen that taking the inner spirit as a pillar, authority is naturally generated. Only teachers with excellent teaching ability and democratic spirit will become the one who wins the admiration of his students with ease. Jaspers' Authority Theory is of great enlightening significance to the reconstruction of modern teacher authority. Since ancient times, people's reverence for teachers and recognition of their authority has been passed down from generation to generation. However, due to various reasons, nowadays people have questioned or even challenged the authority of teachers, gradually damaging teachers' authority image and influence. The existence of teacher authority is in jeopardy under the situation of internal and external threatens. In this study, the author first makes a detailed explanation of Jaspers' Authority Theory, then analyzes the reasons for the fading of contemporary teachers' authority based on the reality, and finally tries to help teachers establish authority again from three aspects: school system, legal guarantee and teachers themselves.
\end{abstract}

\section{Keywords}

Educational Philosophy, Jaspers, Teacher Authority, Fading, Remodeling

\section{Introduction}

Dewey (1991), the famous American philosopher and educator, once said, "Phi- 
losophy is the theory of education as the practice of prudence", "If a philosophical theory has no effect on educational efforts, such a theory must be artificial." As an educator, Jaspers talks about education with a profound philosophy of survival. As a college professor, Jaspers' classes were also popular with students, thus it can be seen that educational thoughts and philosophical thoughts are often in perfect harmony and therefore complement each other. Therefore, it is necessary to further explore educational philosophy to serve our current educational reform.

Through a comprehensive analysis of Jaspers' educational thoughts, there are five relations established, including Communication, Absorption, Edification, Authority and Attitude Theories. Among them, the Authority Theory is mainly embodied in the chapter of "Real Authority as the Source of Education" in his book "What is Education". Jaspers (1991) stressed that the only source and essence of education is faith in authority, without this belief education can only be called teaching technology. The essence of education is the devotion to ultimate values and absolute truth. Jaspers, therefore, divides education into three types: Scholastic, Teacher-apprentice and Socratic. Meanwhile, as Jaspers (2007) stated, all of these three types of education require students to have reverence for the absolute truth and the guide of truth-seeking-the teacher. These educational forms prove that the existence of teacher authority is indispensable. Therefore, what kind of teacher authority is suitable for contemporary education is the most significant thing that educational scholars should think about.

\section{Authority and Teacher Authority}

\subsection{Authority}

Authority is essential for the political, military and educational functioning of a country. It is a combination of inner spirit and outer compulsion. The content of authority is constantly changing; it is naturally generated, discovered and renewed in the process of inheritance. Therefore, authority has the characteristics of spirituality, democracy and spontaneity.

\subsubsection{Spirituality}

Jaspers believed that true authority was backed up by inner spiritual power. Authority is in the heart of human beings and speaks through their own existence. Because authority is planned by human beings, its establishment requires absolute obedience. With a deep understanding of the belief in authority, people regard the unity of freedom and authority as an ideal and believe that authentic authority can only be established by the combination of freedom and authority. However, because there is an opposite relationship between freedom and authority, in the face of the game between the two, people need to maintain the balance between authority and freedom by using underlying spirit.

\subsubsection{Democracy}

Authority is closely related to the free growth of human beings. Pure power, dis- 
tinguished from authority, is despotism, and despotism cannot be endured. Pure freedom, as opposed to authority, is completely arbitrary and ultimately destroyed by the chaos it produces. Authority, therefore, is a combination of will and compulsion, or liberty and despotism, to which even the tyrannical or dictatorial must submit. But this does not mean that authority is blindly obedient to those who are in command in the field. Because inside the authority, people can revolutionize the authority that is out of date, so that the authority feels threatened and agrees to undergo the test of revolution and make changes. To prevent this, authority allows freedom to be opposed to it, thus democracy is born.

\subsubsection{Spontaneity}

Throughout history, Authority has appeared in various forms, whether as absolute status, or as spiritual leaders, or as religious beliefs. The various authorities have different images and power, and they compete with each other internally and externally. People live in a rich variety of authority and it is as indispensable as air. As stated by Jaspers (2005), “Authority is always necessary as a self-styled image of truth that supports all truth; and when it has fallen, it reestablishes itself out of its present confusion, as a master of destiny." Authority, as an image of truth, always exists. Even if it collapses due to various reasons, it can freely evolve to meet people's needs again and make people live in it all the time. If all authority is abandoned and everyone is free to live according to their own ideas, it becomes a new authority to succumb to the idea of "freedom for the sake of blind freedom". Authority is therefore absolute.

\subsection{Teacher Authority}

In the primary stage of human society, it is manifested in the form of "taking nature as the teacher" and "taking God as the teacher". In the Late Middle Ages, Martin Luther's Reformation promoted educational reform as well as secular government. He argued that the right to establish education should be in the hands of the government, but not the church. The government should attach as much importance to education as tax collection and conscription. After the eleventh century, city schools sprang up and developed rapidly, most of which were run by chambers of commerce and subsequently handed over to municipalities. The role of the teacher gradually shifted from the clergy to the secular people. After the Renaissance, religious culture gradually declined. In such a society, the divine authority of teachers is further dissolved. Meanwhile, with the advent of knowledge society, the institutional guarantee of secular regime and the reverence for knowledge, especially scientific knowledge, brought new changes to the basis of establishing teachers' authority.

In the middle of the 20th century, knowledge society approached, knowledge became the center of modern society, and all human affairs are based on knowledge to run. The knowledge society puts forward new requirements for people living in it: to be familiar with the existing knowledge of human society, and to discover and innovate knowledge on the basis of the existing knowledge. This 
inherently poses new challenges to education. On the one hand, the purpose, content and specification of education are bound to change; On the other hand, as the spreader and creator of knowledge, teachers naturally become a significant node in the operation of social affairs. People's attention to the value of knowledge naturally transfers to teachers, and teachers automatically become the knowledge authority in people's eyes.

\section{The Fading of Teacher Authority}

Huge social changes have also made a big impact on education. With Dewey's education theory deeply rooted in people's hearts, round after round of education reform repeatedly emphasized the central position of students in teaching, and students gradually became the master of the classroom. At the same time, the education and training industry is booming. Private schools and training classes are springing up everywhere. In these institutions, the teacher-student relationship is gradually transformed into a business-to-consumer relationship. Triggered by these changes, the position of teachers as the absolute authority in China for a long time is now being shaken imperceptibly.

\subsection{Resolution of Institutional Authority}

A school is a place where people are nurtured and educated in a purposeful, planned and organized way. It will guarantee the operation of education order through a series of rules and regulations, and legalize the authority of teachers. The management of students is the power vested in teachers by the system. However, judging from the actual performance of schools, not enough attention has been paid to teachers. In reality, when parents are not satisfied with the teacher's method or attitude and go to the school to discuss with the principal, the teacher is often asked to apologize to parents and students by the grade director or principal. At the same time, many schools, especially colleges and universities, implement the management method of students evaluating their teachers, so that students become one of the "managers" of teachers. Although the school implemented this strategy to urge teachers to teach better, it has also become a factor that teachers must consider when managing the class. Even when students do not obey the discipline in class, the teacher will also have scruples in management, fearing that the improper management will lead to a low score in their teaching evaluation. In the long run, students become more fearless while teachers' authority is undermined by the power of students, and their role as designers, organizers, and administrators of education and instruction is greatly diminished.

\subsection{Resolution of Traditional Authority}

In the traditional social culture, teachers are often respected, and the Confucian culture in ancient China advocates the dignity of teachers and ethics to an unparalleled height. However, with the development of society and the invasion of 
multi-values, people's tradition of "respecting teachers" is also changing quietly. Students gradually become the center of teaching activities and the main social concern has shifted from teachers to students. What's more, the voice of students' free development is increasingly rising. The continuous filling of students' power space inevitably leads to the continuous compression of teachers' authority space. The rights and demands of teachers gradually fade out of the center of social attention and become a silent area. At the same time, with the continuous development of the market economy, education is gradually industrialized. Many parents believe that in such an economy, money and academic performance should be exchanged equally: parents, who bear the high tuition fees themselves, should naturally get their children's considerable performance, while teachers increasingly become the tools of the education industry to achieve economic benefits. The tradition of respecting teachers is shaky in the environment of the modern market economy, and the traditional authority of teachers is gradually disappearing.

\subsection{Resolution of Knowledge Authority}

The professionalization of teachers requires their own professional authority. The dissolution of teachers' professional authority is manifested in the absence of teachers' paradigm (Shulman, 1986), Pedagogical Content Knowledge (PCK) immediately attracted attention in the field of teacher education research. Lack of teacher PCK makes students question the professional competence of teachers. At the same time, with the development of modern information and communication technology and the influence of diversified knowledge systems, students can acquire enough knowledge through a wide range of channels, and teachers are no longer the single source of knowledge (Hao, 2002). In addition, the situation that teachers only impart curriculum knowledge can no longer meet the needs of current students in today's society. Therefore, nowadays when the PCK standard for teachers has been sharply raised, if teachers cannot possess the corresponding ability and knowledge, their authority will be directly greatly weakened.

\section{The Remodeling of Teacher Authority}

The effective operation of teacher authority needs not only the support of policy and public opinion but also the strength of teachers themselves. Therefore, the remolding of teacher authority also needs the efforts of external support and teachers' own change.

\subsection{Optimize Teachers Institutional Guarantee}

Russell (2010) pointed out that teaching activity is a kind of institutional leadership, so teachers' authority and reputation originate from their institutional status, and teaching activity can only be carried out when teachers gain such authority. In traditional society, teachers' authority is mainly realized by compul- 
sory means such as laws and regulations (Zou, 2011). Without the protection of relevant laws and systems, teachers' authority will easily be challenged and questioned from every aspect. First of all, we should constantly perfect our country's education laws and regulations, to protect the legal authority of teachers obtained by law. Although China has issued "Nine-year Compulsory Education Law", “Teacher Law", "Education Law" and other education laws and regulations, there are still some unsatisfactory aspects in the implementation of their contents. Teachers Law emphasizes more on teachers' obligations, but there are no special legal provisions to protect teachers' authority. In frequent conflicts between teachers and students, public opinion always points the finger at teachers because students are protected by The Law on the Protection of Minors. Even if students are disrespectful in most cases, there are no relevant legal provisions in the teacher's law to protect the rights and interests of teachers, but only moral constraints. Schools also tend to simply reprimand students and cases are therefore dismissed, greatly weakening teachers' authority. Therefore, relevant education laws and regulations should be improved to make clear provisions on the scope of teachers' power and the scope of teachers' punishment to students, so as to safeguard the legitimate rights and interests of teachers and improve teachers' institutional authority.

\subsection{Empower Teachers with More Autonomy and Management Participation}

The establishment of teacher authority needs the support of power, and teachers with power can better teach and manage the classroom. The education management system implemented in the past emphasized the centralization of school management, the stereotyping of classroom teaching mode and the unity of examinations, which severely restricted the play of teachers' teaching autonomy, resulting in the inflexibility and monotony of teachers' teaching, and naturally, it was difficult to establish teachers' internal authority. Although Teachers' Law clearly stipulates that teachers can enjoy the basic rights of teaching and managing in the classroom, teachers' autonomy is difficult to be fully realized due to various practical reasons. At present, school administrators have a serious sense of power and position so teachers' right to participate in school management is always ignored. What's worse, some administrators always interfere in teaching, which greatly dampened teachers' enthusiasm for work. Therefore, China should implement the new curriculum reform, innovate the educational management system, and grant teachers more teaching autonomy and management participation rights in law. At the same time, the implementation of laws in reality should also be taken into account when legislating.

\subsection{Improve Teachers' Professional Knowledge and Ability}

At present, although the teachers are no longer the only authoritative subject of knowledge, the existence of the teacher's knowledge authority still has its value that cannot be ignored. Because of the spontaneity of authority, we "allow stu- 
dents to despise low-performing teachers." (Jaspers, 1991). The "low-performing teacher" mentioned by Jaspers refers to a teacher who not only cannot meet the needs of students with his own knowledge, but also forces students to obey. Therefore, teachers should try their best to persuade people with virtue and talent, in order to truly gain the respect of students.

First of all, teachers should constantly promote their professional development. The realization of teacher professionalization needs not only the support of laws, policies and funds of the government but also the subjective efforts of teachers themselves. Teachers' professional knowledge consists of ontological knowledge, conditional knowledge, practical knowledge and general cultural knowledge. Teachers should constantly study and reflect on their own professional fields, and constantly explore and improve their professional knowledge in all aspects during their practice. In addition, teachers should be good at learning, constant in research, diligent in reflection, and qualified with the courage to practice. They should improve their professional development by actively participating in various projects such as self-education seminars, expert guidance meetings and professional training activities organized by education departments and teaching research institutions.

Secondly, teachers should constantly improve their teaching skills. Chen (2000) believes that a teacher's extensive knowledge is the foundation of acquiring their knowledge authority. However, even if a teacher is well-educated, he or she cannot always flexibly apply this knowledge to teaching and be accepted by students. Then he or she cannot be regarded as a qualified teacher, let alone acquire knowledge authority. Therefore, based on studying the characteristics of modern education, teachers should deeply understand students, grasp the inherent laws of education and teaching, and improve the quality of teaching. Simultaneously, teachers should keep pace with the trend of the times, learn, embrace and then master the new means of modern education and teaching, and break the traditional education model of "three feet platform and one mouth". Teachers should also be able to flexibly use a variety of teaching methods to liven the classroom and stimulate students' interest in learning. Especially in the trend of deepening education and teaching reform, teachers should not only master multimedia teaching technology, but also the spirit of innovation which can constantly create new teaching methods in line with the characteristics of students. Only in this way can they adapt to the trend of our times and make the classroom more vivid, flexible, and interesting.

\section{Conflicts of Interest}

The author declares no conflicts of interest regarding the publication of this paper.

\section{References}

Chen, G. S. (2000). Education Principle. East China Normal University Press. 
Dewey, J. (1991). How We Think. People's Education Press.

Hao, Y. D. (2002). Curriculum and Culture. Educational Science Publishing House.

Jaspers, K. T. (1991). What Is Education. SDX Joint Publishing Company.

Jaspers, K. T. (2007). The Idea of a University (2th ed.). Shanghai People's Publishing House.

Jaspers, K. T. (2005). Existenzphilosophie. Shanghai Translation Publishing House.

Russell, B. (2010). Authority and the Individual. The Commercial Press. https://doi.org/10.4324/9780203864876

Shulman, L. S. (1986). Those Who Understand Knowledge Growth in Teaching. Educational Researcher, 15, 48-52. https://doi.org/10.3102/0013189X015002004

Zou, X. T. (2011). Philosophical Reflection on Teacher Authority from the Perspective of Postmodernism. Journal of Hebei Normal University, 2, 25-29. 